\title{
KRONiK
}

\section{Eylül ve Sonrası}

Prof. Dr. Türkkaya Ataöv

11 Eylül 2001 günü New York City'de "lkiz Kuleler" diye de bilinen Dünya Ticaret Merkezi ile başkent Washington, D.C.'de Pentagon adıyla ünlenen Savunma Sekreterliğine yapılan hava saldırıları savunulamaz. Kapitalizmin ve militarizmin simgelerini hedef aldığı anlaşlan bu eylem birçok yönüyle çlgıncaydi. Saldırının hemen ardından masum insanlardan oluşan kurban sayısı çok daha büyük olarak tahmin edildiyse de, son verilen rakkam 3.000 dolaylarına inmiştir. Sayınun ilk tahminlere göre daha az oluşu olayın önemini o oranda azaltmaz. Kaldı ki, saldın gece uygulanmıs ve bu nedenle de çok az kurban, giderek tek bir kişi bile yitirilmiş olsaydı, en azından bir cinayetin sözünü etmemiz gerekirdi. Birkaç bin sıradan kişi sıcaktan pelte gibi erimek ya da gökdelenlerden atlamak suretiyle akla gelmedik yollardan yaşamın yitirmiştir. Böyle bir kısa "kronik" yazısında terörizmin tanımlamasın uzun uzun yapmak gibi tamamlayıcı bilgiler sunmayı bile denemeden, önce, dünyanın bu türlü eylemlerden kurtulması gerektiğinin altını bir kez daha çizmek zorundayız.

Ne var ki, bir dergide yer alan kronik yazısınun dar çerçevesinde bile, günlük gazetelerin haber gündemini aşan bazı gözlem ve değerlendirmeler gerekecektir. Gene yazının biçiminden ötürü, yazar ve okuyan açısından her ilgili noktanın sözünü etmeğe önce kısıtlı sayfa sayısı izin vermiyor. Buna karşın, Amerika'nun tepkisini hem pratik sonuçlan, hem dış politikasının temelleri yönünden ele almakta yarar var. Afganistan, Taliban ve Usâme bin Ladin'e ilişkin bazı gerçekleri anımsatmakta ve bu saldırı olayının bir yandan dünyayı ve öte yandan da Müslüman alemini bölmesi yerine terörizmden de, uluslararası ilişkilerin günümüzdeki açmazından da çıkar yol gördüğüm bazı önerileri, çok kısa da olsa, konunun içine katmakta da yarar görüyorum.

Taktik yönünden beklenmedik bir başarı olan bu hava saldırısı saldıranlar açısından bakıldığında stratejik bir yanlıştı. Amerika bir şok yaşadı. Ama bu darbeden daha güçü bir biçimde çıkt. Bir bakıma Pearl Harbor deniz üssüne Japon saldırısın (7 Aralık 1941) akla getiriyordu. O olayda Beyaz Saray'ın önderliği o Pazar günü ya da o zamanki Başkan F. D. Roosevelt'in bir gün sonra yaptı̆̆ı kararı konuşmayla değil, onu izleyen uzun yılların zahmetli savaşlarıyla ölçülmüştü. $O$ gün de, 11 Eylülde de Amerika'nın güvenliği ve toprak bütünlüğü saldırıya uğramıştı. Her ikisinde de Amerikan halkı ve önderliği 
haklı olarak öfkeliydi. Beyaz Saray'da başka bir siyasi partinin temsilcisi bulunsaydı da, tepki her iki olayda da değişik olmayacaktı.

Öte yandan, bu benzerliğin dışında önemli farklılıklar da var. Pearl Harbor'da hedef Büyük Okyanus ortasında küçük bir askeri üstü ve bu saldınyı yapan düşmanun kim olduğu ve nerede bulunduğu biliniyordu. 11 Eylülde ise, kimlikleri ve yandaşlar kesin olmayan ve yerleri belli olmaktan çok uzak birileri Amerika'run erişilmez ve dokunulmaz gibi görünen anayurt toprağına, giderek onun en kalabalık sivil yerleşim bölgesine, daha ötesi en simgesel noktalanna fütursuzca saldırmışlardı. Uğrunda Amerikan Anayasasının bile geçici olarak değiştirildiği başarll FDR üçüncü başkanlık süresi içindeydi. Beyaz Saray'a henüz ayağın basmış olan bugünkü Başkan George W. Bush'un önünde ise, türlü bilinmeyenler sıralanup duruyordu. 11 Eylül saldırısının sorumluluğunu üslenen yoktu. Saldırgan olarak kuşkulanılan kişinin yeri belli değildi. Üstelik, bizzat Bush onun yandaşlarının altmış ülkede barındıklarını ileri sürmüştü.

Ne 11 Eylül saldırısın, ne de ona tepkiyi bunlarla aslında bağlantìı olan tüm ögelerden sıyırip ele alabiliriz. Bizzat Amerikan Kongresinin dünyaca ünü kütüphanesinin 1993 yllında yaptığı ve bu devletin dış ülkelerdeki asken̂́ müdahalelerini konu edinen yayınına göre, 1798 ile 1993 arasındaki bu türlü silâha baş vurma olaylarının sayısı $245^{\prime}$ dir. Bu rakam Ikinci Dünya Savaşının bitiminden kitabın yayım tarihine kadar 66'dır. 2001 yılında Afganistan'a müdahaleye kadar kadar olan süre de eklenince $70^{\prime} i$ aşar. Bu gerçeğin akılda tutulmasında yarar var. 11 Eylül saldırısından önce $A B D$ eski Genel Kurmay Başkanu ve şimdiki dışişlerine bakan Devlet Sekreteri General Colin Powell'ın uyarısı da şöyle: "Kafanızı zorlayın. Elimdeki ifritler azahlyor. Elimdeki yaramaz kişiler azalıyor." (Think hard about it. I'm running out of demons. I'm running out of villains).

11 Eylül olayına gösterilen tepki de bir askerî müdahaledir. Bu bağlamda Amerika'nun askerî müdahalelerinin nedenlerini, çok kusa da olsa, akla getirmek gerekir. 1823 Monroe Doktrinini, 1898 Amerikan-Ispanyol Savaşının sonuçların şimdilik bir yana koyalım. Eski Devlet Sekreteri Henry A. Kissinger Diplomasi adlı kitabında diyor ki: "Roosevelt ve Truman tüm dünyayı Amerikan modeline göre yeni baştan dökme durumunda görünüyorlardı. Soğuk Savaş'ın sona erişi uluslararası çevreyi Amerikan imajinda yeniden yaratma yolunda daha da büyük bir istek üretti...Amerika yeryüzünün herhangi bir yerinde müdahale yeteneği olan tek kalmış süper-güçtür".

Şu genel çerçeveyi görmezden gelemeyiz: ABD dünyanun en önde gelen gücü konumuna alışmıştır. Bu konum ona vazgeçemediği ekonomik ve siyasal yararlar sağlamaktadır. Bu yayılmacılığına öylesine alışmıştır ki, onu kendi ideoloji ortağı öteki sermayeci devletlere karşı da savunagelmiştir. Ortak 
düşmana karşı birleşmeyi öngören Soğuk Savaş dönemi sermayeci kampın kendi içindeki bu çelişiyi perdelemiş, bir ölçüde gizlemiştir. Herşeyden önce Amerika ile Sovyetler Birliği'ni askerî, siyasal ve ekonomik yönlerden karşı karşıya getiren bu dönem Ikinci Dünya Savaşının bittiği yıldan 1990'lara değin sürdüğü için, yani bir hayli uzun süreyi kapsadığından, sermaye merkezleri arasındaki rekabetin gereği gibi gözlenmediği söylenebilir. Aslında, ABD-Sovyet çatışmasını berisinde Amerika ile Ingiltere, Fransa ya da Batı Avrupa'nun çekişmesi o denliydi ki, 1945-90 arasını "Iki Kutuplu" yıllar diye niteleyip noktalamak bile bir bakıma eksik ya da yanlış olabilir. Daha doğru olarak, "lki-buçuk" ya da "Üç Kutuplu" dönem de denebilir. O döneme özgü "komünizm tehlikesi" inancindan ötürüdür ki, öteki sermayeci merkezler Amerikan önderliğine açıkca ses çıkarmadılar. Aralarındaki rekabet, olduğu kadarıyla, gizlice sürdü. Soğuk Savaş döneminde bile Amerika'nun bir değil, iki "Çevreleme Siyaseti" vardı - biri komünizme, öteki de sermayeci müttefiklerine karşı. O denli ki, Doğu Blokunun 1989 'dan başlayarak değişmesi ve Sovyetler Birliği'nin de 1991'de dağılması müttefiklerinin de çevrelenmesini, bu kez, Amerika'nun temel hedeflerinden biri durumuna getirmiştir. Bu tutumu yakın geçmişle çelişili değil, onun ön plâna çıkması ve derinleşerek sürmesidir.

Soğuk Savaş yıllarında bile Amerikan öncülüğünün önüne iki engel çımışt: siyasal sol ve bazı sağ gruplar. Solun içinde Batı Avrupa'nın komünist partileri de vardı. Maurice Thorez'in başını çektiği parti Fransa'da 1945'den sonra çok popülerdi ama seçim oyunlarıyla yalnızlı̆ga itildi. Görünürde çok-partili olan Italya'da da (faşizmin yıkılmasından sonra bile) neredeyse tek parti sistemi vardı. Amerika'da 1950'lerin Devlet Sekreteri J.F. Dulles "Bağlantısızlık ahlâksızlıktır" genellemesini yapmaktan sakınmamışt. Oysa, Hayvan Çiftliği ve 1984 'ün yazarı George Orwell de Asya ile Afrika'da da uzantıları olacak (ve her iki bloka da aynu uzaklıkta) bir Avrupa Sosyalist Federasyonu önermişti. Türkiye'de en üst düzey yöneticilerin henüz bugünlerde anlamak zorunda kaldıkları şu gerçek Amerika'nın en yakın müttefiki Ingiltere'de tutucu ve etkili sağ yayında (Economist) şu sözlerle ifade ediliyordu: "Yardım denilen şey ne zaman verilse ona öylesine koşullar ekleniyor ki, en kısa süre içinde daha da kötü koşullarda yeni yardım peşinde koşmaktan başka yol gözükmüyor". Fransa'da Charles de Gaulle kendi ülkesini NATO'dan çekti ve merkezini de Paris'ten çıkardı.

Doğu Blokunun dağılmasından sonra, NATO'nun yaşamın yeni hedefler göstererek uzatmak ve onun çerçevesinde "insancil müdahale" görünümüyle askerî varlık sergilemek Amerika'nın uygulamalarından biridir. Amerika'nın uzun ve başarısız Vietnam deneyimi bu ülke yöneticilerine korkulu düşler gördürmüştür. Askerî üstünlügü elden çıarsa, önderlik konumunu yitirecektir.

"Komünizm-karşıtlığı" Amerika'nun kendi hedeflerine meşruluk kazandırıyordu. Sovyetler Birliği'nin ve Doğu Blokunun varlığı bu meşruluk için gerekliydi. 
1990-91'de Irak'a askerí müdahale (Türkiye'yi büyük zarariara uğrattrken) Amerikan ekonomisini biraz rahatlatı ama sorununu temelden çözmedi. $O$ ekonominin daha başka savaşlara gereksinimi var. "Ulusal güç" dediğimiz kavramı topluca oluşturan çeşitli ögelerin içinde "askerí güç" ve ondan öte "militarizm" Amerikan dıs politikasınun vazgeçilmez bir yanıdır. Bu ülke en büyük askeri varlık olmanun yanıbaşında, tüm dünyadaki toplam askerî harcamaların üçte-birini yapmakta, en çok silâh satan devletler listesinin başındaki yerini korumakta ve silâhlı çatışma yürüten devletlerin de en önündedir. Ayrıca, bu savaşlarda çatışmaların nedenleri olarak ileri sürdüğü savunmalarla gerçek nedenler arasında öylesine farklılıklar vardır ki, Amerikan halkının da, dünya kamu oyunun da sistemli ve sürekli biçimde yanıltıldığı görüşü ağırlık kazanıyor.

Soğuk Savaş bitti ama, Amerika'nun yönettiği "Sıcak Savaşlar" sona ermedi. Amerika'nun Küba'da Guantanamo'dan Oman'da Masira'ya, Grönland'da Thule'den Türkiye'de Incirlik'e, Kanada'da Namao'dan Japonya'da Yokota'ya, Fas'da Sidi Slimane'den Hint Okyanusu'nda Diego Garcia'ya, Ingiltere'de Bedford'dan Avustralya'da Cockburn Sound'a, Norveç'te Oerland'dan Okinawa'da Kadena'ya ve bir anakaranun bir sürü ücra köşesinden başka birinin en tenha uçlarına ulaşmı̧ ve kısa sürede savaşa hazırlanabilecek hava, deniz ve kara kuvvetleri ağı kurulmuştur. Soğuk Savaşın en doruk noktasında bile, Sovyetler Birliği böylesine geniş bir yayılma içinde değildi. Amerika dışında hiçbir ülke uzak diyarlara bu denli sık çatışma amaçlı askerî birlikler yollamamıştır. Amerika'run dünyanun her köşesinde silâhla koruduğu yaygın çıkarları vardır. Bunların niçin ve nerede kullanılacaklarına ilişkin bilgiyi halk medyadan, medya da Beyaz Saray, Savunma ve Dışişleri Sekreterliklerinden almaktadır. Amerikan Kongresinin denge ve basının da denetim görevini neden yapmadığı tarışmasın da şimdilik bir yana koyalım. Ama gerçek şu ki, 11 Eylül saldırısına gelinceye değin, en üst düzey yöneticilerin Amerikan halkını ve dünya kamu oyunu hedefleyen açıklamalarıyla yıllar sonra açlan arşivler arasında çok önemli çelişiler gözlemleniyor. Buna bağlı olarak, birçok kişi savaşa ve bunların bazılan da asıl ne uğruna silâh kullandıklanı bilmeden ölüme gittiler.

Amerikan sermayesi ve militarizmi bu müdahalelere bağımlıdır. "Şeytan Imparatorluğu" (The Evil Empire) ortadan kalktı̆̆ına göre, yüzlerce milyar dolarlık dev askerî bütçe nasıl meşru gösterilecek, Soğuk Savaş yıllarının getirdiği kısıtlamalardan artık kurtulmuş olan rakip sermayeci devletler nasıl dizginlenecektir? Amerika başka bir rekabet, yeni çatş̧ma nedenleri bulmak zorundadır. 1990'lardan bu yana, F. Castro, M. el-Kaddafi ve S. Hüseyin gibi yöneticilerle savaşım, kafa tutan devletleri hizaya getirme, terörizmi yok etme, Kosova örneği "insancl müdahale" ve Samuel Huntington'un önerdiği "Uygarlıklar Çatışması" kabilinden çeşitli seçenekler sunulmuştur da. Irak'ın 
Kuveyt'i işgaline tepki sıkışan Amerikan ekonomisine ancak kısa bir nefes aldırdı, o kadar.

11 Eylül saldınsı ise, bir çeşit "imdada yetişti". Soğuk Savaş olanaklanna yaklaşan yeni bir "Haçlı Seferi" doğmuştu. Askerî harcamalar hemen en üst sınıra dayandi. Ne yapılacaksa, kamu desteği hazır görünüyordu. Başkan Bush vakit geçirmeden ve inandına kanutlan açklamadan Afganistan'da (belki de haklı olarak) Usâme bin Ladin'i suçladı. Kongre'deki konuşmasında da aynca şunlan söyledi: "Gerekli her silâh kullanacağız...Amerikalılar tek bir çatışma değil, şimdiye değin gördüklerimizden çok daha uzun bir kampanya beklemelidir...Ya bizimle ya da teröristlerle birliktesiniz...Bu, dünyanın, uygarlığın savaşıdır...Biliyoruz ki, Tanrı da yansız değildir..." Bu sözler akla şu sorulan getiriyor: 'Her silâh' sözcüklerinin içine nükleer, kimyasal ve biyolojik silâhlar da giriyor mu? Bir seri savaşlar mu olacak? Bunlar sınurlı kalmayacak $\mathrm{m}$ ? Savaş süresine ve hangi ülkelerin hedef olacağına kim karar verecek? Bir uygarlıklar çatışmasına doğru mu sürükleniyoruz? Amerika'daki karar-vericinin her sözüne uymak zorunda mıyzz? Yoksa, teröristlerin safında mı sayılacağız? Aynı seçenek Tann için de mi geçerli? Usâme bin Ladin ile çevresindekileri gösteren kaset filmi gerçekse, bu kişiler de yaptıklan söylenen kanlı eyleme Allah'in hayurlı bir hikmeti gibi bakmıyorlar mı?

Bu ülke demokrasisinin yeni yönünü göstermesi açsından daha ürkütücü olarak, Amerikan Kongresi, yalnuz ve yalnız Temsilci Barbara Lee'nin (Kaliforniya) karşı oyuyla, Başkan Bush'a yeni düşmanlan dilediği gibi seçme ve savaşı gene dilediğince yürütme hakkı tandı. Beyaz Saray'a bağlı aynca bir ļ̧ Güvenlik Dairesinin de (Office of Homeland Security) kurulmuş olması Amerikan demokrasisinin bazı başka darbeleri de göze aldığın gösteriyor. Amerikan televizyonuna egemen olan tekelci çevreler, bir ara, birkaç yüz ünlü şarkının çalınıp söylenmesini de engellediler. Amerikan yönetiminin önerdiği ve kabul ettirmekte olduğu önlemler bu toplumda özgürlükleri daha da sınurlayabilir.

Amerika'daki siyasal ve ekonomik sisteme ilişkin kararları alanlann ve bunlan yürütenlerin kişi özgürlüklerinin kısılması, militarizmin derecesi ya da hedef alınacak ülkelerin sıralanması gibi konularda zaman zaman görüş ayrılığı içinde olmaları da beklenebilir. Giderek, Türkiye gibi bazı müttefiklerin Irak'a da müdahaleye karşı çkmalan gibi farklı eğilimleri de olabilir. Ama son tahlilde, Amerika militarist bir yaklaşımı tüm yeryüzüne yayma stratejisinde başarlı olmuştur.

11 Eylül saldırısınun Amerikan yönetici çevrelerinin kamuyla ilişkilerini kolaylaştırdığını yukarda belirttim. Ama öte yandan, Amerikan modeli küreselleşmenin yalnuz Türkiye gibi ülkelerde değil, bizzat Amerika'da da varlıklıları daha varlıkı yaparken varhksızları daha da yoksullaşııdığın 
eklemeliyim. Amerika'daki belirgin sorun siyasal açdan ileri sürülen eşitçi teorilerle ekonomik yönden hiç de eşit olmayan uygulamaların nasıl bağdaştırlacağ (ve ülkemizde Amerikan modelini savunanlann da içeriğinden genelde habersiz olduğu) Bağımsızlık Bildirisi ile Anayasa gibi tarihsel belgelerin eşitlikten yana olduğu genel bir kanıdır. Bunlara imza koymuş olanların kạ̧nın aynı zamanda köle sahibi de olduklan gerçeğini de bir yana koyalım. Bağımsızlık Bildirisini yazan elin kaçak kölelerin yakalanmasına ilişkin ilan da kaleme aldığın bu bağlamda akılda tutmakla yetinelim.

Bugün için önemli olan Amerika'yı o günden bu yana yönetenlerin vakitlerinin bir bölümünü pek fazla şeyi olmayan çoğunluğun varlıklı azınlıkla aradaki farkı kapamaları için baş vurabilecekleri çözümleri etkilemeğe harcadıklan gerçeğidir. Bu etkilemenin en kısa yolu halk yığınlarının kenđi çıkarları uğruna dökülecekleri meşru yolları tıkamak, onları aktif ve örgütlü siyasetin dışına çekmekti. Amerikan yönetimi de, daha önce başka imparatorlukların yaptı̆̆ gibi, halkı kendi siyasetinin desteğine alma peşindedir. Geçen yüzyılda Britanya "beyaz adamın sorumluluğu"nu ileri sürmüştü; Amerika da bugün siradan yurttaşın demokrasi ve özgürlük şemsiyesi altında göstermek istiyor. Savaş amaçlanın geçmişte eksik ve yanlış açıklayan Amerikan yönetiminin eline 11 Eylül saldırısı nedeniyle yeni bir silâh daha geçti: halkın haklı öfkesi.

Ama yanıltmalar gene de eksik değil. 11 Eylül olayından sonra da Amerikan haber medyası konuyu egemen güçlerin istediği biçimde verdi. Yani, Amerika dünyada demokrasinin, barışın ve insanalluğın en önemli savunucusudur ve militarizmin bu hedefte vazgeçilmez bir rolü bulunmaktadır. Öte yandan, gerçek şu ki, Amerika kendine yaradığı sürece baskıcı rejimleri desteklemiş ve ayakta tutmuş, o ülkelerin demokrasiye yönelmelerini de engellemekten geri kalmamıştır. Dünyadaki zenginliğin önemli bir yüzdesini, nüfusuyla ters orantılı olarak, elinde tutan Amerika'nın siyaseti iki milyar insanın açlıkla ve onunla bağlantılı işsizlik, hastalık, çıplaklık, evsizlik ve eğitimsizlik gibi sorunlarla boğuşması sonucunu doğurmuştur. Amerikan siyaseti içinde Panama'da devlet başkanın kaçırmak, Filipinler'de yok pahasına çocuk iş̧̧i çalıştrmak, Singapur'da grev bastırmak ve Beyrut'ta seksen kişinin ölümü ve iki katının yaralanmasıyla sonuçlanan bombalama olayı da vardır. Amerikan yetkililerinin "yumuşak hedefler" (soft targets) dedikleri bu sivil halk değil midir?

Yukardaki rakam bazı okuyuculara ufak görünebilir. Başka örnekler de yok değil. Amerika'nun Nikaragua'ya 1980 'lerde yaptğı askerî müdahalede binlerce kişi öldürüldü. Nikaragua New York ya da Washington'a terörist saldında bulunmadı, Uluslararası Adalet Divanına başvurdu. Burada alınan karar Amerika'nun yasa-dı̧ı olarak kuvvete baş vurduğunu söylüyor, tazminat ödemesini istiyordu. Amerika tazminat ödemek yerine bir kez daha kuvvete baş 
vurdu. Nikaragua da konuyu Biirleşmiş Milletler Güvenlik Konseyine getirdi. Amerika orada da kendisi aleyhine çlkacak karan ancak vetoyla önleyebildi. Nikaragua, bu kez, B.M. Genel Kuruluna gitti. Burada da Nikaragua aleyhine ancak iki devlet oy kullanabildi - biri Amerika, öbürü de Israil. Bu durumda, Amerika Uluslararası Adalet Divaninun terörizmle suçladığı tek devlet olarak sivrilmektedir. Aynca, uluslararası hukuka uyulmasın isteyen Güvenlik Konseyi kararına ilişkin aykın oy kullanan devlettir de.

Amerika'nun "alçak-yoğunlukta savaş" (low-intensity warfare) dediği silâhlı savaşım biçimi dıs politikasının bir parçasıdır. Öyle görünüyor ki, Amerikan kapitalist sistemi yaşamun sürdürmek için savaş hazırlı̆̆ ve uygulaması dışında etkili bir yol bulamıyor. Kapitalist düzende karar vericilerin içinde büyük sermaye sahipleri ağır basarlar. Onlanın düzeni değiştirmek gibi tasarlan yoktur. Amerikan sermayesinin derin bunalımın FDR'ın New Deal'i de feraha çıkaramamış, sorunu Ikinci Dünya Savaşının dev askerî harcamalan çözmüştü. Bu türlü harcamalarsa, geliri daha adil bölüşmek gibi bir amaçla donanmamıştr. Olsa olsa, muhaliflere baskıyı birlikte getirir. Filistinlilerin Sabra ve Şatila'da katledilmeleri ya da Iraklı sivillerin ölümü dünyayı yerinden sarsmadı. Ama 11 Eylül olayı Amerika'da "Şahinler"in en savaş yanlısı olanlarını karar mevkilerinde herzamankinden daha ağır basacakları konuma getirdi.

Son olayda Amerikan halkının öfkesinin kuşkusuz yeri var. Ancak, bu öfke bu kez de dünyanun başka yerlerindeki masum insanların öldürülmesi gibi bir sonuç doğuracak mı? Tüm toplumların bir ekonomik bunalım içinde olduğu şu surada gelişmemiş ülkeleri ve aralarında yoksul insanları hedef alacak bir tepkinin karmaşaya, giderek patlamalara yol açabileceği de akılda tutulmalıdır. Hemen hemen her savaşta asıl yitirilenin insanlık olduğunu söyleyebiliriz. Böylesine bir çatısma için B.M. Güvenlik Konseyinden karar alınmalı ama bu onay ikinci Körfez Savaşındaki (1990-91) gibi göstermelik olmamalıdır. Amerika'nun başın çektiği Afganistan çatışmasında da insanî değerlere ne ölçüde uyulacaktır? Kuvvete baş vururken uluslararası hukuka uygunluğa dikkat edilmeli, gösterilen tepki onu doğuran tehdidi aşmamalı ve siviller askerî hedeflerden ayrı tutulmalıdır. Nihayet, Afganistan'a müdahale Huntington'un öngördüğü "Uygarlıklar Çatışması"na yol açmamalı, böyle bir olasılığın kapısını bile aralamamalıdır. Ne yazık ki, bazı kapıların açk bırakıldığına ilişkin birtakım sözler var ya da bunjar son tahlilde bir uygarlıklar çatı̧̧masına yol açabilir.

Usâme bin Ladin'e gelince: Onu ve onun terör ağın gizli savaşlarıyla da ün yapmış olan Amerikan Merkezî Haber Alma Örgütü (CIA), Pakistan'ın da yardımıyla, yarattı. Başkent Kâbil'deki solcu yönetimi iktidardan düşürmek için Müslüman kökenli ve önemli ölçüde para için savaşan askerlerden kurulu 
silâhlı güçleri örgütleyenler onlardı. Sovyetler Birliği'ni "Afgan tuzağı"nın içine çeken de bu örgütlemeydi. Dı̧ destekle güçlenen muhalefet Kabil'deki iktidan zor duruma düşürünce, Sovyetler Birliği gaya imdada yetişti. Ama aslında, içinden zor sıyrilacağı bir batağa girdi. Ne ölçüde doğru olduğu kesin değilse de, Afganistan'in kuzey komşusu Sovyet yönetiminin böyle bir tuzağa bilerek çekildiği yorumlan da var. Çok dağlık topraklarda ummadıkları güçlüklerle de karşlaşan Sovyet birliklerinin önüne gitgide büyüyen Mücahitler'in direnci dikildi. Bunlann içinde Taliban gruplan önemli kesimleri oluşturuyordu.

Taliban'ın ardında kendi amaçlan için Pakistan da vardı. Hem kuzey komşusu Afganistan'da kendi "Islâmî Cumhuriyet"iyle uyumlu olacak dinci bir yönetim, hem de Pakistan'ın birliğini zaman zaman tehdit eden Paktunistan sorununda güvenebileceği bir iktidar oluşturmak için. Bağımsızlığın 1947'de kazanmış olan Pakistan kısa sürede ardarda birkaç anayasa gördü, eyâletlerini bir birleştirdi bir ayırdı, doğu kanadı bağımsız oldu, kendi adına "Islâm" sözcüğünü ekledi ve şeriat hukukuna gitgide yaklaştı. Afganistan'a bitişik kuzey-bat bölgesinin Pathan halkı sınrr-ötesindekilerle ayn etnik ve dil grubundandı. Üstelik, Taliban'in, sınır-ötesi Pathanlar'la birlikte, kendine borçlu kalacağını umuyor, her iki ülke topraklannda kurulan çok sayıdaki eğitim merkezlerinde yetişecek militanlar Hindistan'a bağlı Keşmir topraklarında vurucu güç olarak da kullanmayı tasarlıyordu. Son noktaya ilişkin olarak, Afganistan'da iç savaş en alt noktasına ulaştğında, bu silâhlı gruplar Keşmir gibi yeni "istihdam pazarları"na hem kendiliklerinden, hem teşvikle, hem de kontrata dayalı para kazanmak amacıyla aktılar. Taliban ordusu böyle kuruldu, yaşatıldı ve güçlendirildi.

Sovyet ordusunun Afganistan'dan glkması da bu nedenle gecikti. Ne var ki, Suudî Arabistan'dan kalkıp gelen bin Ladin daha sonra, kendi ülkesinin de Amerikan işgåli altunda olduğunu söylemekte gecikmedi. Bu görüşünü açıklarken baskıcı rejimlerin de koruyucusu Amerika'ya karşı öfkelenen geniş kesịmlerin desteğini kazandı. Öte yandan, Israil'in hem elindeki, hem de Başkan Clinton'un karanyla yollanan yeni helikopterleri Filistin halkına karşı kullanması yalnız bin Ladin'i değil, Irak'ta Saddam Hüseyin'i de bazı çevrelerin gözünde daha da popüler yapmaya yaradı. Daha 11 Eylüle gelmeden New York'ta Dünya Ticaret Merkezine 1993'de saldın düzenleyenlerin önemli bir bölümü de Mücahidîn artığıydı.

Suudî, Mısırlı, Cezayirli, giderek Islâmı seçmiş birkaç Amerikalı gibi silâhı bir sürü Müslümanı kapsayıp genelde yanlış olarak "Afganlı" denen bu kişiler liberal sermayeci düzenin heryerde egemen kılmak istediği küreselleşmeye karşı insan pasifleştirdiği için Amerika'nun ylllar öncesinde desteğine kavuşmuşlardı.

Öte yandan, 1979'da Afganistan'da iktidarda olan yönetim lâikti ve 
reformcuydu. Bu amaçların bir bölümünü gerçekleştirdiğini o suralarda Afganistan'a giderek ben de görmüştüm. O zamanki yönetimin modernleşme için biçilmiş kaftan olup olmadiğı ayn bir konudur. Ancak, 11 Eylül saldınss nedeniyle kaleme aldığım bu yazı açısından önemli olan Amerika'daki karar-vericilerin dinci gruplan örgütleyip silâhlandurma siyasetinin bu ülkede sonunda kökten-dinci bir grubu işbaşına getireceğini bildikleridir. Afganistan'daki gerici anlayışın, yerine konmaz Buda heykellerini yok ettiği doğrudur. Ama içinde Peştun, Özbek, Tacik, Hazara, Türkmen, Baluç ve benzerleri bulunan Afgan halkı Buda heykelleri kadar da değerli değil miydi? Kandahar filminin yapımcısı Mohsen Makhmalbaf'ın (sanatç üslabuyla ifade ettiği) şöyle bir yargısı var: "Buda heykeli aslında utancından çöktü. Afganistan'a dünyanun ilgisizliğinin verdiği utançtan".

Amerika ve dostlan iktidara kendine dinci diyenleri getirdikten sonra onlarla halkı başbaşa bırakmak gibi bir umursamazlık (ya da bir onay) içindeydi. Onlann açlı̆̆, ölümü, geriliği ve kötü yönetimiyle Amerika ve CIA ilgilendi mi? Bu durumda, Amerika'nın yetiştirip öne sürdüğü bin Ladin'in günde üç kez sıcak çorba veren "eğitim" kamplarına önce yüzlerce ve sonra binlerce gencin, karın doyurmak için de olsa, koşması doğal sayılmaz mı? Afganistan'da Kuveyt'teki gibi petrol olsaydı, durum herhalde farklı olacaktı. Ama o zaman başkentteki iktidar da Kuveyt'tekine benzeyecekti.

Nükleer Rus denizaltısının batması ve içindekilerin ölümü kuşkusuz üzücü bir olaydi. Dünya televizyonlanın ve basınının, bir süre, haklı olarak bir numaralı haberiydi. Olayı duymayan neredeyse kalmamışt. Buna karşılık, Afganistan'da savaşlardan 2.5 milyon insanun öldüğünü ve (iç göçler dışında) 6.3 milyonun da ülkeyi terkettiğini kaç kişi biliyor? Toplam nüfusun onda-birinden fazlasının yitirilmesinden ve üçte-birinin de göçmen oluşundan tüm dünya ve en başta Amerika sorumlu değil midir? Ayn oranlarn Amerikan nüfusuna uygulasak, yaklaşık 25 milyon ölü ve 75 milyon yurt dışına kaçan göçmen gibi akullara durgunluk veren saylara ulaşmıyor muyuz?

11 Eylül saldınsından birkaç gün sonra Amerika'nun Pakistan'a komşusu Afganistan'a gıda yollamasın engellemesini istediğinde, Taliban'a değil, onun zaten kurban olan halka bir kez daha ceza veriyordu. Bir dünya gücü çkıp da Amerikan halkına yiyecek yollayanların bu yardımı kesmelerini istese ve böylece milyonlarca sivili açlığa ve ölüme mahkâm etse, Amerika'nun tavrı nasıl olurdu?

Neredeyse kusursuz bir tasanmla hayal edilmesi bile zor bir saldirny gerçekleştirdiği kabul edilen terörist grubun bu saldından sonra gelecek tepkiyi de hesaba kattğı düşünülebilir. Bin Ladin'in en azından şimdilik kayılara karışması bu önlemlerin bir parçası olabilir. 
Bu bağlamda bir önemli nokta daha: Taliban ülkeyi bir "Orta Çağ karanlığı"na götürdü, sakal uzatmayı ve kadınları eve kapamayı Islâm'a hizmet sanmak gibi bilgisizlik örneklerini bolca verdi ama, onun egemenliği savaştan bıkmıs halka bir süre barış, ilkel ölçülerde de olsa güvenlik ve bu arada kendi anladığı anlamda adalet te sağladı. Taliban'ın yenilerek çekildiği toprak parçalanında bazı gençlerin zor altında uzattıkları sakalları kestirmeleri ve başkentte iki, üç sinemanun açılması Afganistan toplumunun gereksinimini karşılamaktan çok uzak. Afganistan, kuşkusuz, yüze peçe ve omuza Kalaşnikov takmakla kalkunmayacaktı. Ama, bu kez, traşlı birkaç yüz ve gösterilecek şarkılı aşk filmleri gerçek seçenekler olamaz. Başkentte Taliban'ın yerine oturacak iktidar en az onun sağladığı istikran halka vermek zorundadır. Yapabilirse, çok daha fazlasın ve iyisini de.

Afganistan'daki bütün iktidarlar bu ülkenin, başka şeyler yanunda, önce topografisini dikkate almak zorundadır. Toprak örtüsü başka türlü olsaydı, Afganistan'ın bugünü de farklı olacaktı. Yaklaşık $700.000 \mathrm{~km}$. karenin dörtte-üçünün dağlık oluşu kendiliğinden birtakım çok önemli sonuçlar doğuruyor. Yabancı işgâli zor; onlarla birlikte başka kültürlerin girmesi ve yayılması da kolay değil; ekilecek toprak çok sınırlı kaldığından herkese yetecek ürünü çıkarmak da bir okadar gụ̈; toprağın yüzcyi ticareti desteklemiyor, engelliyor; coğrafya yapısı Afganistan sınırlan içindeki birimlerin teması ve kaynaşması için bile uygun değil; bununla bağlantılı olarak, Afganistan'da uluslaşmanın önünde herşeyden önce dağların yarattığı engel var.

Afganistan'ı Hind'e bağlayan Hayber Geçidi'ni Makedonyalı Iskender, Gazneli Mahmud ve Nadir Şah kullandıysa da, burada savaşlar genelde çok uzundur ve çoğu kez bir sonuca da varmaz. Ülke bu denli dağhlk olmasaydı, Sovyet kuvvetleri böylesine güçlükle herhalde karşılaşmayacaklardı. "Kuzey lttifakı" denen grubun bölgesini Taliban egemenliğinden korumuş olan (Pençsu Vadisini de kapsayan) aynı çok engebeli doğa yapısıdır. Aynı yapı Amerikan askerleri ve buraya savaşmak için gelecek olan her birlik için de en büyük engeldir.

Yollar bu nedenle yoktur. Her yer savaştan ötürü zaten mayınla doludur. Kâbil'de çektiğim bir fotoğraf ayağı ya da bacağı kopmuş insan grupların gösteriyor. Bin Ladin'in bir ara içinde saklandığı söylenen yeralt dehlizleri biraz askeri, biraz kaçakçlık amaçlı yamuk yumuk ulaşım ağıdır. Su kışın donar, baharda afet olup taşar, yazın da kurur. Para, olduğu kadanyla, kaçakçllik, savaş ve cinayet üçgeninin patronlarınun elindedir. Bu yönden birçok kuzeyli patron güneydekilerden pek farklı değildir. Tüm ülkede modernizmin simgesi ellerdeki silâhlar. Doğu'nun geleneksel hançeriyle kılıcınun yerini Kalaşnikov ile Stinger füzesi almıs. 
Afganistan'ın geliri uyuşturucu ile doğal gazdan geliyor. Birincisi yılda 500 milyon, ikincisi de 300 milyon dolar getiriyor. Ama dışardaki yabancı araciann uyuşturucudan yllık kazana 79.5 milyar dolar. Demek ki, toplam 80 milyarın neredeyse tamamu dışardaki araciların cebinde kalıyor. Uyuşturucu ülkeden düşük değerle çıkı Avrupa ve Amerika pazarlannda çok yüksek fiatlarla alıa buluyor. Bu kâr bölüşümünden memnun görünen yabancinın Afganistan'ı modernleştirmek ve kalkındırmak gibi amacı yok. Yılda toplam 800 milyon dolarlık gelir eşit bölünse bile, kişi başına günde bir ekmek parası düşer. Ama $o$ gelir de eşit bölünmüyor. Afganlıların tümü uyuşturucu tüccarı değil. Bu gelir kaynağ çetelerin elinde.

Ortalama ömür çok düşük. Kadının durumu erkeğinkinden daha da kötü. Reformcu yönetim zamanında Dişişleri Bakanlığında görev yapan aydın, iyi yetişmiş ve becerikli bir Afgan kızı bize "bu iktidar ilerici olduğunu söylüyor. Bakanlık giriş sınavlarını erkekler gibi benim de kazanmıs olmama karşın, bana ne bir oda ne de oturacak bir masa gösterdiler. Koridorlarda dolaşıp duruyorum. Savaşı herhalde kendine dinci diyenler kazanacak. Kadınlar olarak durumumuz o zaman daha da fena olacak" demişti. Yeni dinci iktidar şu inancı yayma peşindeydi: Afgan kadın tüm bedenini saran "çadır"ı ve peçesini çkarırsa, Allah onu kara taşa çevirir. Bu ülkede bir zamanlar Afgan nüfusu kadar $\left(20 \mathrm{~m}\right.$.) kocabaş hayvan zenginliği vardı. 1930'lu ve $1940^{\prime} \mathrm{l}$ y yıllarda Türkiye'nin yolladığı çok sayıda veterinerin yardımıyla hastalıklardan arınan ve çoğaltılan o hayvanlar da yirmi yıllık savaşa ve kıtlığa dayanamayıp telef oldular.

Sayılan 2.500'ü aşan Taliban eğitim merkezlerine çoğunlukla aç gençlerin gittiğini bilmek zorundayız. Onlar için asgarî gıdalarla karın doyurduktan sonra savaşmak, Kur'an ezberlemek ve olursa kaçakçllı yapmaktan başka iş yok. Muhaliflerin büyük çoğunluğu da benzeri durumda. Onların da yağmur duasına çıkma, uyuşturucu olarak dışa satılacak ürünü ekip toplama ve silâhlı çatışmalan sürdürme dışında bildikleri ve olanakları son derece sınurlı. Durum böyle olunca, dıs güçler de içteki hiziplerden hangisi işlerine geliyorsa onu desteklemekle yetiniyorlar.

Usâme bin Ladin yakalanup yok edilse bile, yalnız askerî tepki Islâm dünyasını bir de bu yönden bölecek, ortaya yeni Bat hedeflerine terörist yöntemlerle saldırmayı tasarlayan çok sayıda başka insanlar çıkacaktır. Terörizm herhalde en etkili biçimde onu besleyen kaynakları kurutmakla son bulur. Amerika barışın ve adaletin gerçekten öncüsü olsa, bin Ladin ve benzerleri yandaş toplayabilir mi? Afgan halkının sorunları çözüm yoluna girse, Taliban kendiliğinden zayıflamaz mi?

11 Eylül saldırısı daha tehlikeli olan bir buz dağının yalnız en üstündeki ucunu 
gösteriyor. Görünen yüzeyin altındaki asl büyük bölüm insanlı̆ın Amerika'nun ekonomik, siyasal, diplomatik, askerî ve kültürel baskısından bezen ve modernleşmeden payını alamamış olan ama insanlığın çoğunluğunu oluşturan büyük kitlenin şikâyetlerini simgeliyor. Buz dağınun tepesini yok etmek asıl büyük çelişiyi ortadan kaldırmaz. Çözüm bu temel çatışmanun yok edilmesidir. Bunun için de günümüzdeki Amerikan modeli küreselleşmenin yerine birbiriyle bağlantılı ve birçok ögeyi kapsayan şu seçeneğin geçmesidir: "insanal bir küreselleşme". B.M. Genel Sekreteri Kofi Annan 11 Eylül saldınsınun neden olduğu tartışmanın dünya düzeninin yeni baştan ele alınup görüşülmesi için bir fırsat yaratmış olması açısından önemli olduğunu söylemişti.

Sözü edilen tartş̧ma yalnız dünya zenginliğini daha adil bölüşme sorunu da değildir. Insancil küreselleşme önerileri, çok kısaca, şöyle özetlenebilir: (1) Demokrat düşünürlerin en iyi öğretilerine uygun olarak, yurttaşlar hak ettikleri otorite konumuna yüceltilmelidir. (2) Demokrasi tüm toplumlan ve kişi yaşamının her yanun içine alacak biçimde genişletilmelidir. (3) Bunun için içte eğitim, dışta işbirliği gerekir. (4) Toplumlar içinde küçük farklılıklar korunabilirse de, bunlar ayrımcilığın nedeni olmamalıdır. (5) Anlaşmazlıkların barış̧ yoldan çözümünde, adalet yollarına bağlı kalma da dahil olmak üzere, yasa egemenliği saygı görmelidir. (6) Şiddete dayalı uygulamalara karşı çkarak, barış̧̧ savaşım geleneği güçlenmelidir. (7) Çatışma ve savaş biçimleri yeniden elden geçmeli, uluslararası hukuk yeni baştan düzenlenmelidir. (8) Taraflar eylemlerinden ötürü kişisel olarak da hesap vermelidir. (9) Savaşın yasa-dışı olduğu uygulamada da görünmelidir. (10) "Güç dengesi" siyasetinin yerini yasaların ağır bastı̆̆ küresel bir güvenlik sistemi almalıdır. (11) Yeni bir küresel çevre bilinci oluşmalıdır.

Yukarda yalnuz birer cümleyle özetlenen öneriler pazara yönelik, militarist ve insancıl olmayan bir küreselleşmenin karşısında yer almaktadır. Bu öneriler yanlı̧ küreselleşmeyi kabul ettirmek isteyen ve 11 Eylül saldırılanna dayanak hazırlayan güçler için sanki birer tehdittir de. Ancak, terörizmin kökünün kazınması için de, daha adil ve demokratik uluslararası toplum için de başka bir seçenek görünmüyor. 